\title{
Study on the Development Strategy of Chinese Processing Industries
}

\author{
Jing $\mathrm{Ma}^{1, \mathrm{a}}$ \\ ${ }^{1}$ Xijing University, Xi'an,710123 \\ a email532824757@qq.com
}

Keywords: Chinese Processing Industries, Development Strategy, Economic Index

\begin{abstract}
Since the reform and opening up, Chinese processing trade has grown in strength, it has become the leading trade Chinese foreign trade. However, Chinese processing trade industry chain is short! Narrow radiating characteristics that make economic dependence inevitably, can not forming lasting impetus to the economic development of many scholars to express their views on this issue that:! Chinese development of processing trade, at best, can only be a stopgap period of time under certain conditions, the state has adopted recommendations related to macroeconomic policies, swelling processing trade size is limited. China needs not require the development of processing trade. If needed, the next step should be how to develop and to improve the rate of domestic value added processing trade, to achieve its promoting lasting economic growth thesis as a research target and to analyze.
\end{abstract}

\section{Introduction}

Processing trade means business activities mainly in the form of bonded import some or all of the raw materials used for production from abroad, including ingredients and excipients, in the territory of tissue processing and assembly, and then finally finished bonded re-exported. In accordance with the Processing Trade Industries to import materials classified ownership in Chinese domestic production enterprises engaged in processing trade, the main organization of production including processing and feed processing modes. Feed processing means imported materials for the production of enterprises are usually purchased by business payment, ownership of the materials and parts by processing enterprises of all business after processing, production of organizational behavior of exporting finished products; processing is an enterprise for the production of of all imported materials and parts purchased by foreign businessmen and offers free, commissioned by deep processing enterprises, Chinese enterprises do not need to pay for the purchase of foreign exchange, business processing or assembly, only charge processing fees, foreign customer is responsible for product sales business activities. Processing and feed processing as compared to companies in the organization of production with greater operational autonomy, but also to achieve higher profit margins, it is clear that the complexity of production and business organizations greater ability in all aspects including financial, management level, the higher the quality of personnel requirements, bear the business risk is greater. In addition, it is worth noting that Chinese Processing Trade Industries in production and operation time, there are also a large number of foreign manufactures OEM production of OEM production behavior, which is commonly referred to as $0 \mathrm{EM}, 0 \mathrm{DM}$ and the like.

\section{Chinese Processing Trade Industries Classification and Its Features}

Processing Trade Industries with distinctive features and principles of co-operation, the situation is more complex, covering a wide range of industries. Our main investment in processing trade production mainly includes three categories: foreign capital, the state-owned capital, private capital, corresponding to the Processing Trade Industries mainly includes foreign-owned, joint ventures, state-owned enterprises, private enterprises. According to the characteristics of the production Processing Trade Industries, usually by the import and export business of many classify Chinese Processing Trade Industries can be divided into large Processing Trade Industries, large-scale Processing Trade Industries, medium-sized and small enterprises and processing trade Processing 
Trade Industries. In general, large Processing Trade Industries export finished products imported materials each year the amount of more than \$10 million in general, large enterprises annually between 6 million and \$ 10 million the amount of imported materials and export of finished pieces, medium-sized export finished products annually imported materials Amount between 50 million to \$ 6 million per year is a small business enterprises export finished products imported materials amounting to $\$ 500,000$ or less.

Processing Trade Industries through various different channels of imported materials and parts, materials and parts, the use of its production capacity and technology, and processed into finished products for export, and then get reflected in the foreign exchange value. Chinese Processing Trade Industries production and operation of enterprises from the general characteristics of the "two out" and "in large quantities", which is the purchase of raw materials and finished goods sales business enterprise production and operation of these two basic organizational aspects are outside the market carried out, so our interactive Processing Trade Industries with the international market is very high, a greater dependence on the international market commodity prices, quality standards, etc., directly influence and control of the production and operation of enterprises. Chinese Processing Trade Industries is the main business activities of production and operation, which is mainly imported materials and parts are organized processed or assembled into finished products. At present, Chinese Processing Trade Industries, although there are raw materials purchasing, sales and many other aspects, but there is no doubt that the manufacturing operations are part of the central link, but also the main business enterprises. Goods from the life-cycle analysis, Chinese Processing Trade Industries through the deep processing of output goods are usually already in the mature stage, and some even in recession. This is because companies outside the country is mainly based on comparative advantage and take advantage of our low cost conditions, commissioned by the Processing Trade Industries in the production of such goods, in order to maximize profits. Therefore, Chinese processing trade production showed the characteristics of low-margin, low-tech. Government mainly through electronic manual and electronic books mode of Processing Trade Industries to supervise and services in this regulatory approach, all models as well as customs clearance efficiency of customs clearance formalities speed directly determines how much business logistics costs, for to rely on earn processing fees as the main source of corporate profits of Chinese Processing Trade Industries, is bound to cause a non-negligible impact.

\section{The Future Development Trend of Chinese Processing Trade Industries}

In the future for a long period of time, the international division of labor in our country's comparative advantage of labor resources is still very significant. First, the number of surplus labor to consider, our country is still one of the world's largest. The statistics show that as of the end of 2011, the number of Chinese total population up to 134,735 people, an increase of 644 million over the previous year, at the end of the national employment 76420 million, of which the urban employed 35914 people. The urban registered unemployment rate was 4.1 percent, the same as the previous year. The total stock of migrant workers is 25278 million, an increase of 4.4 percent over the previous year. Which migrant workers 15,863 million, up 3.4\%; local migrant workers 9415 million, an increase of 5.9\%, the remaining amount of labor is quite enormous. Secondly, the "World Development Indicators 2010" of the relevant statistics show that between 2009 an 2011, the manufacturing sector labor cost per worker of Chinese workers just $\$ 729$, the equivalent of 1/40 of American workers, workers of the yen of 1/43, 1/5 South Korean workers, India

$1 / 2$ workers. It is because of this "large and cheap" workforce as the basis, even in a highly cost-competitive global marketplace, Chinese Processing Trade Industries to develop production Yang also has a significant competitive advantage. In the environment of international economic integration and global division of labor in-depth development of Chinese enterprises are still actively engaged in the processing trade, its development trend is still thriving, not shrinking. Chinese Processing Trade Industries the role of rationality and effectiveness in the allocation of resources irreplaceable, greatly promoted the development of national economy. However, in most of our business is Processing Trade Industries in international division of labor of production of 
low-end, value-added manufactured goods that can be achieved rate is not very high; for the production and procurement of materials and parts from abroad, directly stimulate the national economy not so obvious. But I think, must realize that the overall quality is not high quality of our labor force, have received low compared to the proportion of the total population of Gao and other education personnel occupied, Chinese Processing Trade Industries in production and business activities, often together in simple operation electronic assembly, processing of footwear, clothing and other low-end segment, Chinese Processing Trade Industries to vigorously Jian exhibition business, play an important role in solving the employment, income, etc., to narrow the income gap; if Chinese Processing Trade Industries to achieve overall upgrade, then the use of foreign capital, absorbing the world advanced technology, etc., can play a more important role. Therefore, governments at all levels, all departments will further develop processing trade as the focus of work, so as to promote the great development of Processing Trade Industries.

\section{Overall Strategic Choice of Chinese Processing Trade Industries}

Since most of Chinese Processing Trade Industries were located in the position of the value chain of low-end processing, by the above SWOT analysis, transformation and upgrading of Chinese Processing Trade Industries face common difficulties and pressure, the development of new processing trade have in common, it should implement the following the overall development strategy.

Chinese Processing Trade Industries should seize the strategic adjustment of multinational companies the opportunity to accelerate the pace of development. First, optimize the restructuring process in the new round of world industrial transfer and factors of production, multinationals have worldwide in the new round of production factors as well as the allocation of resources to optimize the integration, and gradually invest more in product located research and development of the value chain. Chinese Processing Trade Industries in maintaining the number of finished products continues to grow at the same time, it is important to firmly grasp the development of processing trade Young favorable conditions and important opportunity, business management focus effectively turn improve the quality and effectiveness, proactively enterprise management model innovation, promote the transformation and upgrading of Processing Trade Industries. Second, the Canadian trade enterprises should be good through the industry cluster advantages and strengthen production level of support, so as to promote the upgrading of enterprises. Industrial Cluster mode compared to a single enterprise, with more professional and sophisticated and centralized features, thus giving them greater management fees and operating costs in the management of innovation and technological innovation are also more flexible, while technology spillover effects and economies of scale in effect after the success of innovation is also more pronounced. Therefore, enterprises should actively by aggregating effect processing trade industry, promote finished updating and upgrading of enterprises.

From strategic planning to consider long-term development, structure and morphology of Canadian business enterprises must upgrade from labor-intensive to capital-intensive technology. Mainly in the following aspects: First, the Processing Trade Industries take the initiative to expand trade of high-tech business, upgrade transition from labor-intensive to technology and capital-intensive. The second is the Processing Trade Industries to actively promote internal labor-intensive sectors, the main part of the assembly process of parts to upgrade technology, capital-intensive sectors, namely the finished product research, design aspects. Chinese Processing Trade Industries to cultivate their own research and development capabilities. Chinese Processing Trade Industries should seize the opportunity to trade booming high-tech world, make full use of favorable policy environment for Processing Trade Industries innovative technology in the development of high-tech enterprise development plan based on the business advantages of resources more investment in scientific research personnel reserve and on research and development activities, by establishing the corresponding innovation incentives, among other measures, within the enterprise to expand high-tech finished processing trade, increase efforts to cultivate the ability of independent research and development of enterprises, expand their own core technologies to 
cultivate and promote the process trade business OEM-ODM "(4)BM evolution, the formation of independent brands, the development of independent intellectual property rights.

Enterprises from foreign-led transition to domestic enterprises oriented. Most of Chinese Processing Trade Industries is the main foreign-funded enterprises, in order to change this situation, the next step of the transformation and upgrading of Processing Trade Industries should focus on encouraging, supporting, nurturing strong domestic enterprises to participate in the development of processing trade, more private enterprises should be actively involved in processing trade business, the nature of state-owned enterprises and private enterprises to strengthen the nature of ownership in the business of processing trade. P In order to coordinate the development into the regional economy, but also in order to ensure the sustainable development of Chinese Processing Trade Industries Yang, governments at all levels should make full use of the opportunity to upgrade the Processing Trade Industries to achieve the formation of Chinese Processing Trade Industries, industrial structure and technological level from east westward advancing of regional division of labor a new situation, in order to maximize the processing trade business interests. Second, enterprises should actively promote the production to "low carbon" machining direction transition from high-energy-based processing, in order to achieve the processing trade business to a "low carbon" direction successful transformation and upgrading, should be strictly in accordance with the standard IS014000 environmental management of the new system, constantly revised and improved technology system; the development of Chinese Processing Trade Industries planning to increase the content resource saving technological progress, environmental protection, etc. aspects.

\section{Conclusion}

Chinese Processing Trade Industries in the most low-end value chain, extending to the two high-end value chain is the only way to achieve business transformation and upgrading. This paper attempts to apply the theory of Chinese Processing Trade Industries to achieve strategic choice to explore the transformation and upgrading in order to "smile Theory" and other theories as the main line, using a number of strategic analysis tools to make growth-oriented strategy, reversing type strategy, diversification three general overall strategy of the four strategic business strategy, defensive strategy, and the expansion of domestic sales strategy, technology leadership strategy, low-carbon development strategy. At the same time, the significance of the implementation of these strategies, Strategy, path until aspects elaborated, to construct a complete system of corporate restructuring and upgrading strategy, with a strong practical and operational guidance, in the hope of Chinese Processing Trade Industries upgrade to make some contribution.

\section{References}

[1] Feenstra, Robert C. and Gordon H. Hanson Intermediaries in Entrepot Trade. HongKong Re-exports of Chinese Goods [J]. Journal of Economics and Management Strategy, 2002.

[2] Feenstra, RobertC, Gordon H. Hanson, Ownership and Control in Outsourcing to China: Estimating the Property-Rights Theory of Firm [J]. The Quaterly Journal of Economics, 2005..

[3] John Humphrey, Hubert Schmitz. How Does Insertion in Global Value Chains affect Upgrading in Industrial Clusters. Regional Studies.2002, (36. 9).

[4] Helene Sicotte, Ann Langley. Integration mechanisms and R \& D project performance [J]. Journal of Engineering and Technology Management. 2000.1.

[5] J. Henri Burgers, Justin J.P. Jansen, Frans A.J. Van den Bosch, Henk W. Volberda. Structural differentiation and corporate venturing: The moderating role of formal and informal integration mechanisms", Journal of Business Venturing, 24, 2009. 